\title{
THE ORIGIN OF CLINOPYROXENE IN CRATONIC MANTLE
}

\author{
Nicolas Coussaert ${ }^{1}$, Michel Grégoire ${ }^{2}$, Jean Claude Mercier $^{3}$, Dave Bell $^{4}$, Daniel Demaiffe ${ }^{5}$, \\ Anton le Roex ${ }^{6}$ and Luc André ${ }^{1}$
}

${ }^{1}$ Musée Royal d'Afrique Centrale, Belgium; ${ }^{2}$ Observatoire Midi-Pyrénées, France; ${ }^{3}$ Université de La Rochelle, France;
${ }^{4}$ Arizona State University, USA; ${ }^{5}$ Université Libre de Bruxelles, Belgium; ${ }^{6}$ Cape Town University, South Africa

Kimberlite magmas from six well known kimberlite localities on the Kaapvaal craton (Bultfontein, Jagersfontein, Monastery, Premier Thaba Putsoa and Letseng) have sampled numerous mantle garnet lherzolites in addition to garnet harzburgites. The Bultfontein kimberlite has also sampled two main groups of phlogopite-rich mafic xenoliths.

\section{PHLOGOPITE-RICH MAFIC XENOLITHS}

Two groups have been distinguished. The first group corresponds to MARID rocks characterised by the mineral association Mica - Amphibole - Rutile - Ilmenite Clinopyroxene (figure 1) and the second group consists of PIC rocks characterised by the mineral association Phlogopite-Ilmenite-Clinopyroxene. The two groups are clearly distinguished from one another by the major element composition of their phlogopite and ilmenite, by the trace element content of their clinopyroxene and by their $\mathrm{Sr}$ and $\mathrm{Nd}$ isotope ratios. They both represent deep mantle segregations from high alkaline melts. The combined major and trace element variations are interpreted to indicate a genetic relationship between the PIC rocks and Group I kimberlite magma, and between the MARID rocks and Group II kimberlite magma (Grégoire et al., 2002).

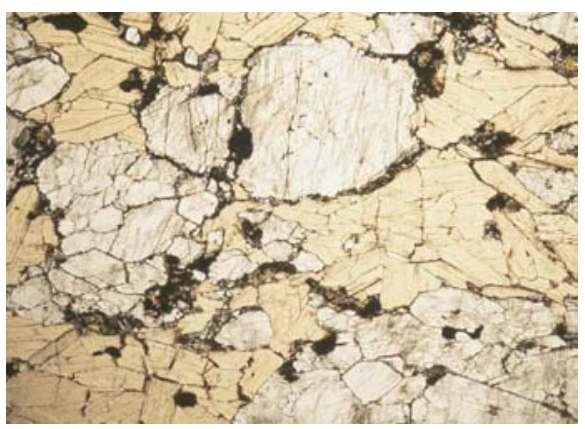

Figure 1: MARID xenolith

\section{GARNET LHERZOLITES}

Trace element characteristics of constituent clinopyroxenes allow two groups of garnet lherzolites to be distinguished (figure 2). This classification is based solely on the clinopyroxene compositions, and the two types of garnet lherzolites include phlogopite-free and phlogopite-bearing samples as well as coarse and deformed samples. Trace element compositions of all clinopyroxenes are characterised by enrichment in LREE and LILE and by a relative depletion in $\mathrm{Ti}, \mathrm{Nb}, \mathrm{Ta}$, and to a lesser extent $\mathrm{Zr}$ and Hf. However, the LREE enrichment and the depletion in $\mathrm{Nb}$ and $\mathrm{Zr}$ (Hf) are less in the Type 1 clinopyroxenes than in the Type 2 clinopyroxenes.

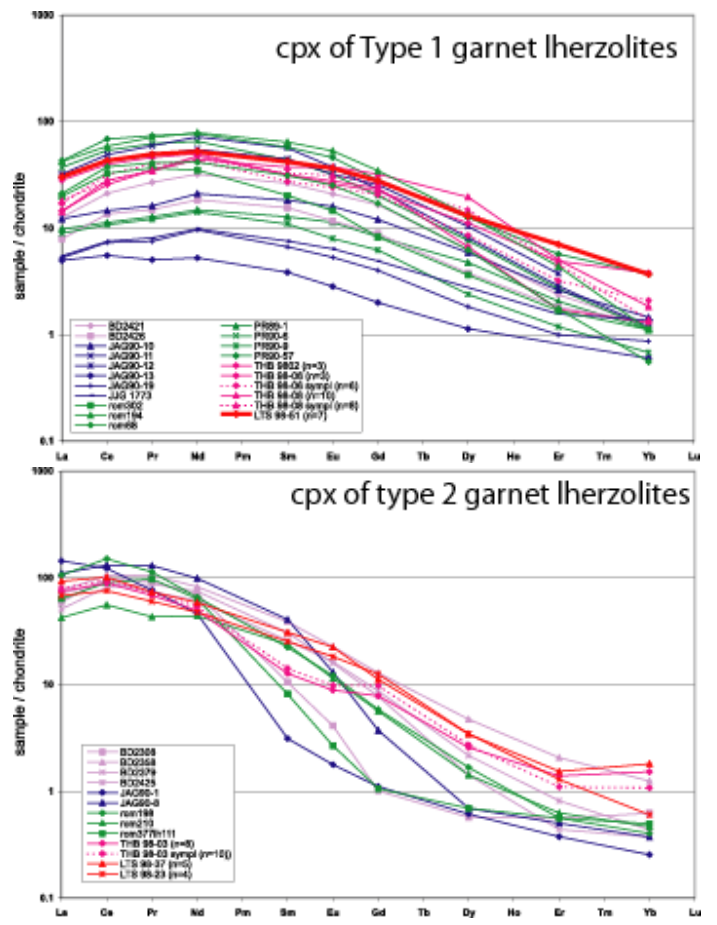

Figure 2: REE concentrations normalised to chondrites of clinopyroxenes of Type 1 and Type 2 garnet lherzolites. 


\section{EVIDENCE FOR METASOMATISM}

The petrographic and chemical features noted in our samples are typical of previously studied peridotite xenoliths from the Kaapvaal craton in presenting abundant evidence for mantle metasomatism. The most direct evidence is the occurrence of primary textured phlogopite in many samples, a feature widely accepted to result from the infiltration of fluid or melt into solid mantle rock (i.e. mantle metasomatism) (eg Erlank et al., 1987; Harte, 1987). Further modal evidence for metasomatism is not apparent in the present sample suite, although we consider below the possibility that clinopyroxene may also be of metasomatic origin.

The trace element compositions of all clinopyroxenes analyzed are characterised by strong enrichment in LREE and other incompatible trace elements and many garnets exhibit the sinusoidal REE patterns inferred to be related to reactions with metasomatic agents (e.g. Hoal et al., 1994; Van Achterbergh et al., 2001). These incompatible element enrichments occur in all rocks, including those where phlogopite was not noted, suggesting either that its presence has been overlooked in some samples or that trace element enrichment may proceed without the growth of mica. This latter case may be of widespread occurrence in Kaapvaal xenoliths (Harte, 1987) and is analogous to similar occult enrichment in peridotite xenoliths from basalt (e.g. Kempton et al., 1999). Because of the ubiquitous trace element enrichment, the presence or absence of primary phlogopite in low-temperature cratonic garnet peridotite may in many cases reflect more the scale of sampling than the metasomatic history of the sample

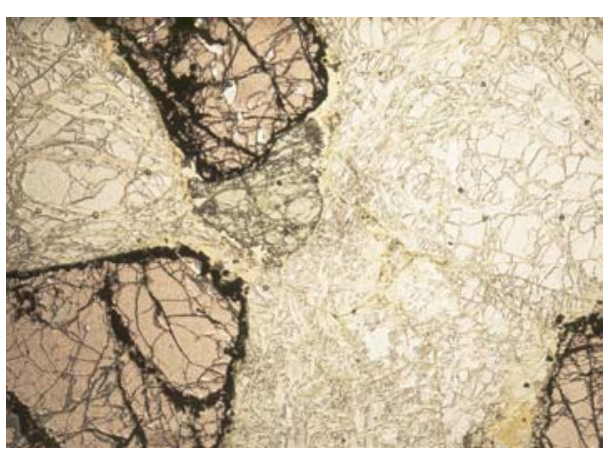

Figure 3: Texturally-equilibrated clinopyroxene of primary appearance in a garnet peridotite

\section{METASOMATIC CLINOPYROXENE}

Texturally-equilibrated clinopyroxene of primary appearance in cratonic garnet peridotite (figure 3) may be a constituent of the original solid assemblage residual from partial melting, be exsolved from it upon cooling (e.g. Cox et al., 1987) or of primary metasomatic origin (Erlank et al., 1987; Van Achterberg et al., 2001; Grégoire et al., 2003). If primary phlogopite is accepted as an indicator of modal metasomatism in the present sample suite, the potential for a metasomatic origin of the clinopyroxene in our samples needs to be discussed.
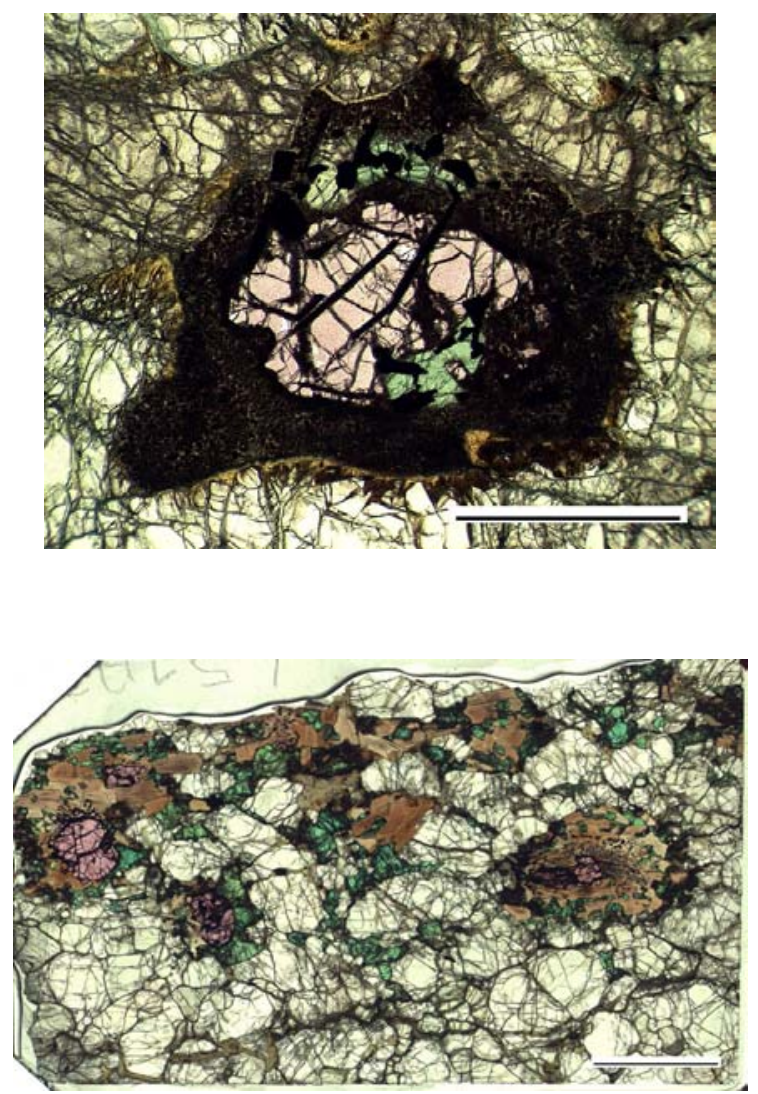

Figures 4 and 5: Clinopyroxene replacing garnet (top) and clinopyroxene associated with phlogopite in microfractures and pockets (bottom) .

In some of our garnet lherzolites, textural relationships highlight the metasomatic nature of the clinopyroxene: spatial associations with phlogopite and spinel, occurrences in symplectites related or not to garnets, in area of metasomatic replacement of garnet, crystallisation in healed microfractures (figures 4 and 5). In the other hand these clinopyroxenes display the same trace element characteristics than those of texturally-equilibrated clinopyroxene of apparently garnet lherzolites primary appearance occurring in the other studied (figure 2). Many of the clinopyroxenes are also high in $\mathrm{Na}_{2} \mathrm{O}$ and $\mathrm{Cr}_{2} \mathrm{O}_{3}$, a characteristic attributed to metasomatic origin in similar kimberlitic xenoliths and in numerous mantle xenoliths in basalts (eg Grégoire et al., 2000; Van Achterberg et al., 2001). As noticed by Van Achterberg et al. (2001) for the 
mantle xenoliths from the Letlhakane kimberlites, our trace element data suggest cases of disequilibrium between garnet and clinopyroxene. Indeed the DZrcpx/garnet ranges from 0.1 to 125 , whereas equilibrium cpx-garnet pairs (of similar major element composition and equilibrated at similar P-T conditions) have DZrcpx/garnet $<1.9$ (Van Achterbergh et al., 1998). Five samples (Group 1: JAG90-11, PR90-6, PR90-57; Group 2: rom198, rom377lh111) have DZrcpx/garnet substantially greater than 2 and are probably disequilibrium assemblages.

Finally, clinopyroxenes from both Type 1 and Type 2 garnet lherzolites display REE- and trace element patterns almost identical to those of clinopyroxenes from PIC and MARID rocks, respectively (Figures 2 and 6). These patterns are repeated in clinopyroxenes from obviously modally metasomatized rocks of the phlogopite wehrlite and PP-PKP type associations (Grégoire et al., 2002). Their appearance in the present suite of xenoliths is therefore a strong motivation for us to consider the possibility that these clinopyroxenes may also be metasomatic in origin.
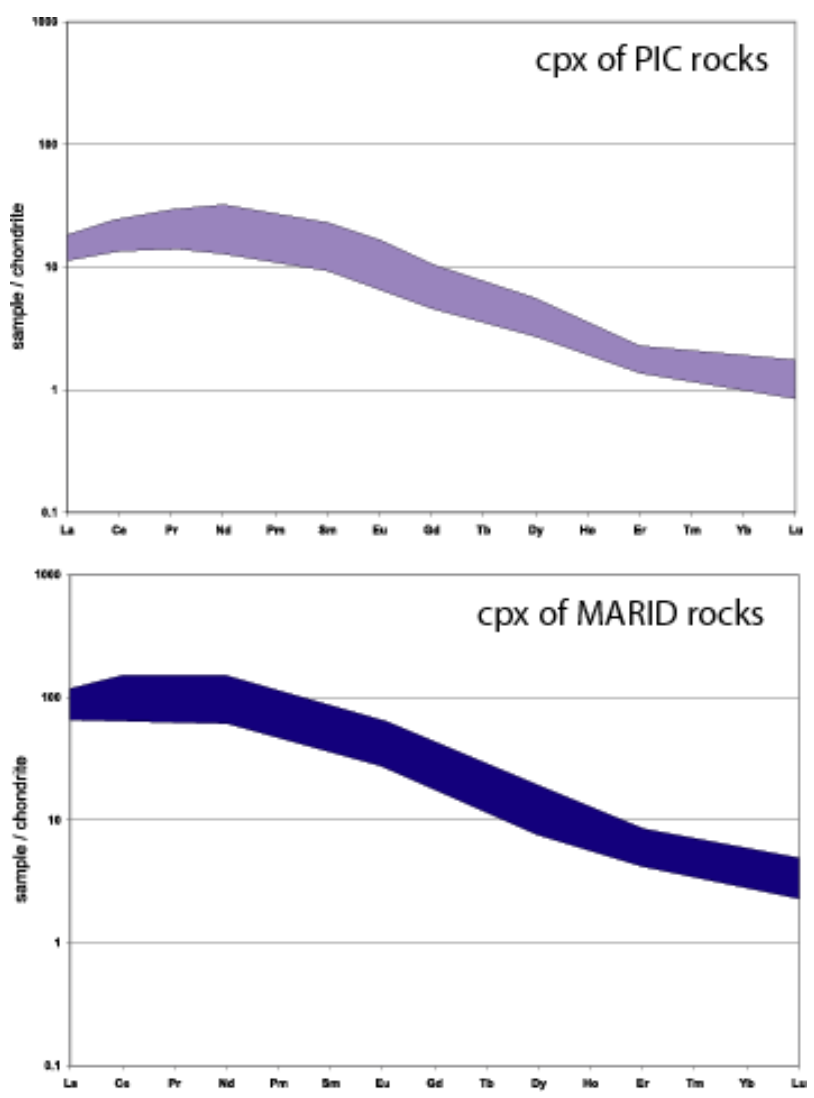

Figure 6: REE concentrations normalised to chondrites of clinopyroxenes of PIC and MARID rocks.

\section{NATURE OF THE METASOMATIC AGENTS}

Both types of garnet lherzolite are rich in elements such as $\mathrm{Sr}, \mathrm{Ba}, \mathrm{Rb}, \mathrm{K}, \mathrm{Na}$ and LREE. Of particular note is that they both appear to be depleted in $\mathrm{Ti}, \mathrm{Nb}, \mathrm{Ta}$, and to a lesser extent $\mathrm{Zr}$ and Hf. However, based on the trace element compositions and patterns of the clinopyroxenes from the two types of garnet \pm phlogopite lherzolites (Type 1 and Type 2), it seems that at least two different metasomatic agents have affected the mantle beneath the Kaapvaal craton. Type 2 clinopyroxene is for example more depleted in $\mathrm{Nb}$ than Type 1 clinopyroxene. The similarities between (i) Type 1 clinopyroxene and PIC clinopyroxene and (ii) Type 2 clinopyroxene and MARID clinopyroxene suggest genetic links. It is proposed, therefore, that the melts responsible for modal metasomatism of the Type 1 and Type 2 garnet lherzolites have a genetic relationship to melts responsible for the formation of PIC and MARID rocks, respectively. The assemblage of metasomatic minerals crystallized in the two types of garnet lherzolites (clinopyroxene, phlogopite), together with the assemblage of minerals observed in PIC and MARID xenoliths (clinopyroxene, phlogopite, K-richterite, ilmenite, rutile, sulphide), argues for crystallization from silicate melts rather than fluids, as previously proposed by Harte et al. (1993) for a similar range of samples. We therefore propose that the two melt types responsible for the metasomatic imprints observed in the two types of garnet lherzolites studied here are highly alkaline mafic silicate melts.

To better assess the nature of these two metasomatic agents, we calculated melt compositions in equilibrium with clinopyroxene in the two types of garnet lherzolites. We used a set of clinopyroxene-alkaline mafic silicate melt partition coefficients. The melts in equilibrium with the two types of clinopyroxenes show a similar limited range of compositions. The two melt types display similar positive $\mathrm{Ba}$ anomalies and negative $\mathrm{Ti}$ anomalies. The only significant differences are the higher LREE contents and strong negative $\mathrm{Nb}$-Ta anomalies of the melts in equilibrium with Type 2 clinopyroxene. The Type 2 melts also have lower HREE abundances than melts in equilibrium with Type 1 clinopyroxene and display negative $\mathrm{Zr}$-Hf anomalies. These contrasting characteristics indicate either (i) the action of two chemically distinct, genetically unrelated, metasomatic melts that have similar trace element contents, or (ii) two metasomatic melts that are genetically related. In case (i) the differences between the two melts could be related to a higher carbonatitic component in the metasomatising, highly alkaline mafic silicate melt responsible for Type 2 clinopyroxene, in that the higher LREE content and strong negative $\mathrm{Nb}-\mathrm{Ta}-\mathrm{Ti}$ anomaly are features typical of carbonatitic melts (e.g. Yaxley et al., 1998). It should be noted that these features could also reflect the presence of a subduction-derived component in the source of this melt (e.g. Grégoire et al., 2001). 
In case (ii) the two melts could evolve from one another by a differentiation process, such as the percolative fractional crystallisation process of Harte et al. (1993) which could in our case explain the higher LREE abundances (and slightly lower HREE abundances) of the Type 2 metasomatising melt. In this case the negative $\mathrm{Nb}$, $\mathrm{Ta}, \mathrm{Zr}$ and $\mathrm{Hf}$ anomalies could be related to the significant crystallization of Ti-oxides, such as rutile and ilmenite, during the evolution from melt 1 to melt 2 . Both ilmenite and rutile are known to be potential reservoirs for HFSE (Erlank et al., 1987; Grégoire et al., 2002). The variation in LREE/HREE ratio, resulting in crossovers in the MREE range, between the two melts could also be linked to the extent to which melt differentiation has occurred in the presence of garnet (Harte et al., 1993). Grégoire et al. (2002) similarly recognised that the magmas parental to the MARID and PIC xenolith suites could relate to one another through a percolative fractional crystallisation process. Ionov et al. (2002) propose a similar process, chromatographic fractionation during reactive porous melt flow, to explain the trace element characteristics of the two types of mantle spinel peridotite xenoliths from Spitsbergen. They argue that this process could produces a variety of enrichment patterns in a single event.

Based on the trace element contents, $\mathrm{Rb}-\mathrm{Sr}$ and $\mathrm{Sm}-\mathrm{Nd}$ isotopic compositions of clinopyroxenes, a genetic link has been proposed between the PIC rocks and the Group I kimberlites (Grégoire et al., 2002) and between the MARID rocks and the Group II kimberlites (Sweeney et al., 1993; Grégoire et al., 2002). Grégoire et al. (2002) argued that PIC rocks and MARID rocks are deep-seated segregations from highly alkaline melts genetically linked to Group I and Group II kimberlite magmas, respectively. We therefore propose that clinopyroxenes of Type 1 garnet lherzolites have crystallized from, or been completely equilibrated with, metasomatic agents related to PIC parental magmas and Group I kimberlite magmas. In many cases, where trace element disequilibrium between clinopyroxene and garnet is preserved, this clinopyroxene may be entirely new, i.e. have grown in a harzburgitic protolith, as proposed by Van Achterbergh et al. (2001) for the Letlhakane samples.

Clinopyroxenes in Type 2 lherzolites have metasomatic trace element compositions that display similarities to clinopyroxene from MARID rocks. They have crystallized from, or been completely equilibrated with, metasomatic agents linked to MARID-parental magmas and Group II kimberlite magmas. The published ages for Group II kimberlite magmatic activity range from 110 to 156 Ma with one locality at $\sim 200 \mathrm{Ma}$ (Smith et al., 1985; Allsopp et al., 1989). It may, therefore, be significant for the proposed Type 2 garnet lherzolite clinopyroxenesMARID rocks-Group II kimberlites link that Type 2 clinopyroxenes have not been identified in xenoliths from the mid-Proterozoic Premier kimberlite but occur in garnet lherzolites uplifted by group I kimberlites (80-100 $\mathrm{Ma}$ ) younger than the group II kimberlites.

\section{CONCLUSIONS}

Trace element characteristics of clinopyroxenes from garnet lherzolite xenoliths from the Kaapvaal Craton point to a metasomatic origin and allow the recognition of two distinct types. Clinopyroxenes of the Type 1 lherzolites have trace element similarities to PIC rocks (Gregoire et al., 2002), and appear to have crystallized from, or been completely equilibrated with, a metasomatic melt with the genetic relationship to Group I kimberlites. Clinopyroxenes of Type 2 lherzolites have metasomatic trace element compositions that display similarities to clinopyroxene from MARID rocks. They are interpreted to have crystallized from, or have completely equilibrated with, a metasomatic agent genetically linked to Group II kimberlites.

\section{REFERENCES}

Allsopp, H.L, Bristow, J. W., Smith C. B., Brown, R., Gleadow, A. J. W., Kramers, J. D., Garvie, O. G., 1989. A summary of radiometric dating methods applicable to kimberlites and related rocks. Proceedings of the IVth International Kimberlite Conference, Perth, Australia, vol 1, 343-357.

Cox, K. G., Smith, M .R., Beswetherick, S., 1987. Textural studies of garnet lherzolites: evidence of exsolution origin from high-temperature harzburgites. In: Nixon, P. H. (ed.) Mantle Xenoliths. New York: John Wiley, 537-550.

Erlank, A. J,, Waters, F. G., Hawkesworth, C. J., Haggerty, S. E., Allsopp, H. L., Rickard, R. S., Menzies, M., 1987. Evidence for mantle metasomatism in peridotite nodules from the Kimberley pipes, South Africa. In: Menzies, M. \& Hawkesworth, C. J. (eds.) Mantle Metasomatism. London: Academic Press, 221-309.

Grégoire, M., Moine, B. N., O'Reilly, S. Y., Cottin, J. Y., Giret, A., 2000. Trace element residence and partitioning in mantle xenoliths metasomatized by highly alkaline, silicate- and carbonate-rich melts (Kerguelen Islands, Indian Ocean). Journal of Petrology 41, 477-509.

Grégoire, M., Bell, D. R., Le Roex, A. P., 2002. Trace element geochemistry of glimmerite and MARID mantle xenoliths: their classification and relationship to phlogopite-bearing peridotites and to kimberlites revisited. Contributions to Mineralogy and Petrology, 142, 603-625.

Grégoire, M., Bell, D. R., Le Roex, A. P., 2003. Garnet lherzolites from the Kaapvaal craton (South Africa) : trace element evidence for a metasomatic history. Journal of Petrology, (in press, scheluded for march 2003).

Grégoire, M., McInnes, B. I. A., O'Reilly, S. Y., 2001. Hydrous metasomatism of oceanic sub-arc mantle, Lihir, Papua New Guinea. Part 2 : Trace element characteristics of slab-derived fluids. Lithos 59, 91-108.

Harte, B., 1987. Metasomatic events recorded in mantle xenoliths; an overview. In Nixon, P. H. (ed.) Mantle Xenoliths. Chichester: John Wiley \& Sons, 625-640.

Harte, B., Hunter, R. H., Kinny, P. D., 1993. Melt geometry, movement and crystallization, in relation to mantle 
dykes, veins and metasomatism. Philosophical Transactions of the Royal Society of London A342, 1-21.

Hoal, K. E. O., Hoal, B. G., Erlank, A. J., Shimizu, N., 1994. Metasomatism of the mantle lithosphere recorded by rare earth elements in garnets. Earth and Planetary Science Letters 126, 303-313.

Ionov, D.A., Bodinier, J.L., Mukasa, S.B., Zanetti, A., 2002. Mechanisms and sources of mantle metasomatism: major and trace element compositions of peridotite xenoliths from Spitsbergen in the context of numerical modelling. Journal of Petrology, 43, 2219-2259.

Kempton, P. D., Hawkesworth, C. J., Lopez-Escobar, L., Pearson, D. G., Ware, A. J., 1999. Spinel \pm garnet lherzolite xenoliths from Pali Aike, Part 2: trace element and isotopic evidence on the evolution of lithospheric mantle beneath southern Patagonia. In: Gurney, J. J., Gurney, J. L., Pascoe, M. D. and Richardson, S. H. (eds.) The J.B. Dawson Volume, Proceedings of the 7th International Kimberlite Conference. Cape Town: Red Roof Design, 415-428.

Smith, C. B., Gurney, J. J., Skinner, E. M. W., Clement, C. R., Ebrahim, N., 1985. Geochemical character of southern African kimberlites: a new approach based on isotopic constraints. Transactions of the Geological Society of South Africa 88, 267-280.

Sweeney, R. J., Thompson, A. B., Ulmer, P., 1993. Phase relations of a natural MARID composition and implications for MARID genesis, lithospheric melting and mantle metasomatism. Contributions to Mineralogy and Petrology 115, 225-241.

Van Achterbergh, E., Griffin, W. L., Shee, S. R., Wyatt, B. A., Sharma, A. L., 1998. Natural trace element distribution coefficients for garnet, clino- and orthopyroxene: variations with temperature and pressure. Extended abstract of the 7th International Kimberlite Conference, Cape Town, 934-936.

Van Achterbergh, E., Griffin, W. L., Stiefenhofer, J., 2001. Metasomatism in mantle xenoliths from the Letlhakane kimberlites: estimation of element fluxes. Contributions to Mineralogy and Petrology 141,397-414.

Yaxley, G. M., Green, D. H., Kamenetsky, V., 1998. Carbonatite metasomatism in the southeastern Australian lithosphere. Journal of Petrology 39, 1917-1930.

Contact: N Coussaert, Musée Royal d'Afrique Centrale, 13

Leuvensteenweg, B-3080, Tervuren, Belgium. E-Mail :

ncoussae@africamuseum.be 